\title{
Potensi Skeletonema costatum (Greville) sebagai Fikoremediator Logam Berat Timbal (Pb) Limbah Batik
}

\section{Potency of Skeletonema costatum (Greville) as Phycoremediator of Heavy MetalsLead (Pb) in Batik Waste}

\author{
Rafael Rape Liwun $^{1}$, L. Indah Murwani Yulianti ${ }^{*}$, Boy Rahardjo Sidharta ${ }^{1}$ \\ ${ }^{1}$ Prodi Biologi, Fakultas Teknobiologi, Universitas Atma Jaya Yogyakarta \\ Jl. Babarsari no. 44, sleman, Daerah Istimewa Yogyakarta, Indonesia \\ Email: indah.yulianti@uajy.ac.id_*nenulis untuk korespondensi
}

\begin{abstract}
The domestic batik industry produces liquid waste which is generally not carried out properly so that the waste contaminates the waterbody. The heavy metals content in the batik industry liquid waste is lead $(\mathrm{Pb})$. Fecoremediation using Skeletonema costatum microalgae is one solution to reduce $\mathrm{Pb}$ levels. The research experiment used RAL (complete randomized design) with three repetitions over 7 days of treatment with variations in inoculum density in the form of V1 (control, without microalgae), V2 (inoculum density $2 \times 10^{5}$ cell $/ \mathrm{ml}$ ), V3 (inoculum density $4 \times 10^{5}$ cell $/ \mathrm{ml}$ ) and $\mathrm{V} 4$ (inoculum density $6 \times 10^{5} \mathrm{cell} / \mathrm{ml}$ ) The results showed that $\mathrm{V} 4$ treatment was the most effective in reducing $\mathrm{Pb}$ levels in batik waste with a decrease in percentage of $36.453 \%$ and decreasing BOD levels in batik waste with a decrease percentage of $81.006 \%$.
\end{abstract}

Keywords: Microalgae, Phycoremediation, Skeletonema costatum, batik liquid waste, lead

\begin{abstract}
Abstrak
Industri batik domestik menghasilkan limbah cair yang umumnya pengolahannya tidak dilakukan dengan baik sehingga limbah tersebut mencemari badan air. Salah satun kandungan logam berat pada limbah cair industri batik adalah timbal (Pb). Fikoremediasi dengan menggunakan mikroalga Skeletonema costatum adalah salah satu solusi menurunkan kadar $\mathrm{Pb}$. Percobaan penelitian menggunakan RAL (rancangan acak lengkap) dengan tiga kali pengulangan selama 7 hari perlakuan dengan variasi kepadatan inokulum berupa V1 (kontrol, tanpa pemberian mikroalga), V2 (kepadatan inokulum $2 \times 10^{5} \mathrm{sel} / \mathrm{ml}$ ), V3 (kepadatan

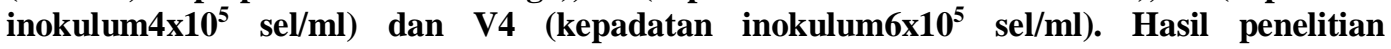
menunjukkan perlakuan V4 paling efektif menurunkankadarPb dalam limbah batik dengan persentase penurunan 36,453\% dan menurunkan kadar BOD dalam limbah batik dengan persentase penurunan $81,006 \%$.
\end{abstract}

Kata kunci: Mikroalga, Fikoremediasi, Skeletonema costatum, limbah cair batik, timbal

Diterima: 04 Desember 2019, disetujui: 14 Januari 2020

\section{Pendahuluan}

Hal yang perlu diperhatikan dari industri batik adalah pengolahan limbahnya tidak dilakukan dengan baik. Masalah ini untuk industri batik skala kecil umumnya diakibatkan oleh keterbatasan tempat, penguasaan teknologi dan manajemen yang kurang bagus dan terutama kurangnya kepedulian pada lingkungan. Sementara untuk perajin yang telah memiliki Instalasi Pengolahan Air Limbah atau IPAL, tidak dimanfaatkan dengan baik karena dianggapmembebani (Eskani et al., 2005).

Umumnya limbah cair industri batik langsung dibuang ke lingkungan tanpa diolah terlebih dahulu. Limbah ini mengandung zat pewarna yang dibuat dari zat organik bersifat non-biodegradable yang sulit terurai (dapat terurai oleh sinar UV, namun lambat) sehingga mudah terakumulasi pada tanah dan badan air (Sitanggang, 2017).

Menurut Soeprobowati dan Hariyati (2013), fikoremediasi adalah alternatif dari 
teknik bioremediasi dengan menggunakan kemampuan alga yang mampu meremediasi dengan baik dengan menawarkan restorasi lahan yang ramah lingkungan, penyerapan ion selektif, serta mampu beradaptasi pada kehadiran logam berat.

Salah satu jenis alga yang dapat digunakan sebagai fikoremediator adalah Skeletonema costatum. Kemampuan absorbsi logam berat oleh Skeletonema sp. terbagi menjadi absorpsi dan adsorpsi, mekanisme absorpsi terjadi akibat kemampuannya untuk menghasilkan fitokelatin (protein yang dihasilkan sebagai bentuk adaptasi pada paparan logam berat) (Nassiri et al., 1997). Mekanisme adsorpsi terjadi akibat dinding sel Skeletonema costatum yang mengandung gugus fungsional berupa hidroksil yang mampu mengikat ion logam berat (Knauer et al., 1997).

Skeletonema costatum, pada penelitian Soedarti et al. (2016) digunakan dalam bioremediasi pada air laut yang terkontaminasi $\mathrm{Pb}$ dengan efisiensi adsorpsi tertinggi dengan nilai $80,50 \pm 0,50 \%$ pada perlakuan inokulasi $5 \times 10^{3} \mathrm{sel} / \mathrm{mL}$ pada konsentrasi $2 \mathrm{ppm}$ hari pertama perlakuan dengan lama waktu 5 hari perlakuan. Pertumbuhan tertinggi diperoleh pada perlakuan kepadatan $15 \times 10^{3} \mathrm{sel} / \mathrm{mL}$ dengan konsentrasi $\mathrm{Pb} 1 \mathrm{ppm}$ yaitu terhitung jumlah sel $13,30 \times 10^{4} \mathrm{sel} / \mathrm{mL}$ pada hari kedua. Penelitian ini akan menggunakan Skeletonema costatum dengan variasi perbedaan kepadatan sel inokulasi awal untuk diaplikasikan pada limbah batik dalam upaya menurunkan kadar logam berat timbal $(\mathrm{Pb})$ yang terkandung di dalam limbah.

\section{Metode Penelitian}

\section{Bahan dan Alat}

Bahan yang digunakan adalah biakan Skeletonema costatum dari Balai Besar Pengembangan Budidaya Air Payau Jepara, bubuk $\mathrm{Pb}$ Asetat, limbah cair Batik Plentong Yogyakarta, aquades, pupuk Walne dan air laut.

Alat yang digunakan dalam penelitian berupa propipet, gelas ukur, thermometer Lovibond, gelas benda, gelas penutup, haemocytometerAssistent, autoclave HVE-50 Hirayama, refraktometer Atago, aerator, selang, lampu TL 40 watt, $\mathrm{pH}$ meter Lovibond, Spektrofotometer Serapan Atom (SSA) Agilent
Technologies 50 AA, mikroskop trinokuler Olympus CX4, hand tally counter, erlenmeyer Pyrex, timbangan analitik Adam England PW254, handphone, kapas, tissue dan karet gelang.

\section{Pengambilan Sampel}

Sampel limbah cair batik diambil dari Batik Plentong Yogyakarta. Botol atau jerigen sebagai wadah sampel dibilas dengan limbah cair sebanyak 3 kali. Sampel limbah cair diambil sebanyak 5 liter (Badan Standarisasi Nasional, 2008).

\section{Sterilisasi Alat}

Alat yang terbuat dari bahan gelas berupa erlenmeyer, propipet, gelas ukur, pipet ukur dicuci dengan air yang mengalir dan diberi detergen, lalu dikeringanginkan. Tahap selanjutnya, alat gelas disterilisasi dengan autoklaf dengan pengaturan suhu $121^{\circ} \mathrm{C}$ dan tekanan sebesar $1 \mathrm{~atm}$ selama 15 menit. Alat non-gelas berupa aerator dan selang aerasi dicuci dengan air mengalir dan detergen, lalu dikeringanginkan (Selvika et al., 2016).

\section{Pembuatan Medium Stok}

Medium untuk pertumbuhan populasi awal alga berupa air laut yang diambil dari Balai Besar Pengembangan Budidaya Air Payau Jepara, Jawa Tengah sebanyak 3 liter disaring dan disterilkan secara mekanik dengan filter bag, lalu diukur salinitasnya. Salinitas disesuaikan dengan penambahan aquades hingga berada di kisaran 25 ppt dengan bantuan alat refraktometer. Tahap berikutnya, ditambahkan pupuk Walne dengan perbandingan volume medium dan volume pupuk 100:1 (Selvikaet al., 2016 dengan modifikasi).

\section{Aklimatisasi Biakan}

Biakan Skeletonema costatum diambil dari Balai Besar Pengembangan Budidaya Air Payau Jepara, Jawa Tengah, diaklimatitasi pada medium yang telah dibuat sebanyak 1 liter pada 3 wadah berbeda. Wadah medium yang telah dibuat, masing-masing ditambahkan $300 \mathrm{ml}$ biakan Skeletonema costatum, fitoplankton diaklimatisasi selama 5 hari (Armanda, 2013) dengan modifikasi.

Lampu TL dengan daya 40 watt digunakan sebagai sumber suplai cahaya untuk proses fotosintesis pada alga (intensitas cahaya setelah diukur yaitu 3,364 lux), lalu kondisi 
lingkungan pertumbuhan pada suhu $20-25^{\circ} \mathrm{C}$, salinitas 25-29 ppt, pH 7-8 dengan dipasang aerator sebagai alat pemberi aerasi pada medium kultur dengan tujuan nutrien dapat tersebar merata. Kultur mikroalga diperbanyak terlebih dahulu sebelum ditambahkan pada perlakuan (Armanda, 2013) dengan modifikasi.

\section{Uji Pendahuluan Fikoremediasi}

Limbah cair batik yang telah diuji awal di Laboratorium Teknik Lingkungan Institut Teknologi Yogyakarta disiapkan, lalu dibagikan ke dalam 3 erlenmyer perlakuan kontrol dan 9 erlenmeyer perlakuan penambahan alga. Variasi penambahan kepadatan sel alga inokulasi awal sesuai referensi Soedarti et al. (2017) yaitu V1 (kontrol negatif tanpa penambahan inokulum mikoalga), V2 (kepadatan awal mikroalga $5 \times 10^{3} \mathrm{sel} / \mathrm{ml}$ ), V3 (kepadatan awal mikroalga $10 \times 10^{3} \mathrm{sel} / \mathrm{ml}$ ) dan V4 (kepadatan awal mikroalga $15 \times 10^{3} \mathrm{sel} / \mathrm{ml}$ ). Medium diberikan aerasi dan pencahayaan dengan lampu neon 40 watt, lalu dilakukan perhitungan kepadatan sel hari ke-0, 2, 4 dan 7. Viabilitas sel mikroalga selama 7 hari perlakuan dilihat, apabila terdapat kematian di hari-hari awal perlakuan, kepadatan awal sel ditingkatkan hingga viabilitas mikroalga tahan selama 7 hari perlakuan dan diperoleh hasil bahwa dengan kepadatan awal $S$. costatum $2 \times 10^{5} \mathrm{sel} / \mathrm{ml}$ mampu hidup cukup baik, dan kepadatannya awalnya ditingkatkan lagi pada nilai $4 \times 10^{5}$ $\mathrm{sel} / \mathrm{ml}$ dan $6 \times 10^{5} \mathrm{sel} / \mathrm{ml}$ agar diperoleh kepadatan awal $S$. costatum yang paling efektif menurunkan kadar logam $\mathrm{Pb}$.

\section{Pemberian Perlakuan dalam Fikoremediasi}

Limbah cair batik dari Batik Plentong disiapkan, lalu dibagikan ke dalam 3 erlenmyer perlakuan kontrol dan 9 erlenmeyer perlakuan penambahan alga. Limbah batik dengan penambahan $\mathrm{Pb}$ diberikan variasi penambahan kepadatan sel alga inokulasi awal, V1 (kontrol) tidak diberikan alga sebagai kontrol negatif, untuk V2 diberikan alga dengan kepadatan awal $2 \times 10^{5} \mathrm{sel} / \mathrm{ml}$, untuk $\mathrm{V} 3$ diberikan alga dengan kepadatan awal $4 \times 10^{5} \mathrm{sel} / \mathrm{ml}$, dan untuk V4 diberikan alga dengan kepadatan awal $6 \times 10^{5} \mathrm{sel} / \mathrm{ml}$. Aerasi diberikan dan diatur $\mathrm{pH}$ dan intensitas cahayanya dengan sumber dari lampu neon 40 watt. Setiap hari dilakukan pengamatan $\mathrm{pH}$, salinitas, dan suhu, serta pada hari ke-0, 2, 4 dan 7 dilakukan perhitungan kepadatan sel alga, sedangkan pengukuran kadar $\mathrm{Pb}$ dan $\mathrm{BOD}$ dilakukan pada hari ke-0 dan hari ke-7 (Wisudyawati, 2014 dengan modifikasi).

\section{Analisis Data}

Data hasil penelitian fikoremediasi oleh penambahan Skeletonema costatum dengan variasi perbedaan kepadatan sel inokulasi awal terhadap kandungan logam berat timbal $(\mathrm{Pb})$ dianalisis dengan program aplikasi SPSS versi 15.0 dengan uji ANOVA untuk mengetahui ada tidaknya beda nyata antar perlakuan. Apabila ada beda nyata, dilanjutkan dengan Duncan's Multiple Range Test (DMRT) pada tingkat kepercayaan 95\% (Gazpers, 1991) agar diketahui letak beda nyata antar perlakuan

\section{Hasil dan Pembahasan}

\section{Identifikasi Mikroalga}

Identifikasi mikroalga dilakukan dengan melihat secara langsung morfologi mikroalga $S$. costatum dengan mikroskop trinokuler dengan perbesaran 400x. Hasil identifikasi morfologi sel $S$. costatum dilihat pada Gambar 1 .

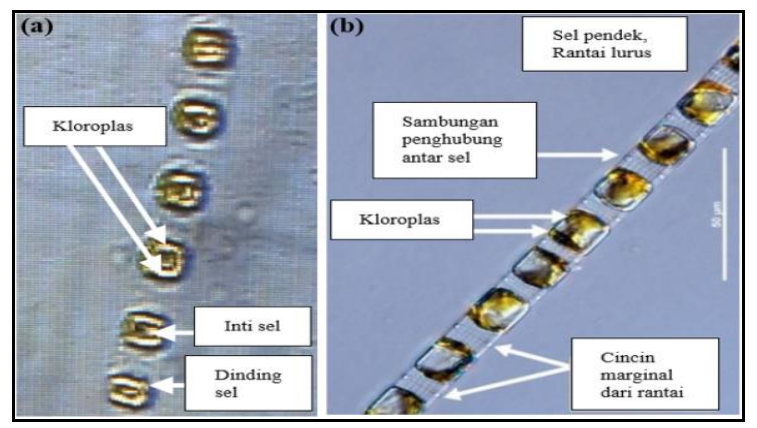

Gambar 1.Morfologi sel $S$. costatum dengan dengan perbesaran 400x hasil identifikasi (a) dan morfologi sel $S$. costatum menurut Department of Earth, Ocean and Atmospheric Science UBC (b) (2018) 
Hasil identifikasi morfologi sel $S$. costatum menunjukkan sel mikroalga ini berbentuk silindris pendek dengan inti sel terletak di tengah dan terdapat kloroplas mengitari inti sel. Satu sel dengan sel lainnya berdekatan dan terhubung oleh suatu rantai yang panjangnya tidak tentu, sedangkan untuk warna mikroalganya yaitu warna coklat sesuai dengan pernyataan Armanda (2013), bahwa akibat dari pigmen xantofil yang dimilikinya, S. costatum berwarna cokelat. Hasil identifikasi ini sesuai dengan karakteristik sel menurut Department of Earth, Ocean and Atmospheric Science The University of British
Columbia (2012) bahwa sel berbentuk silindris pendek dengan inti sel di tengah yang dikelilingi dua kloroplas, serta dihubungkan dengan rantai panjang lurus, sehingga umumnya selnya berderet-deret lurus sesuai panjang rantainya, juga untuk warnanya yaitu coklat kekuningan.

\section{Kepadatan Sel Skeletonema costatum}

Berdasarkan perhitungan kepadatan sel $S$. costatum yang dilakukan diperoleh hasil pada Gambar 2.

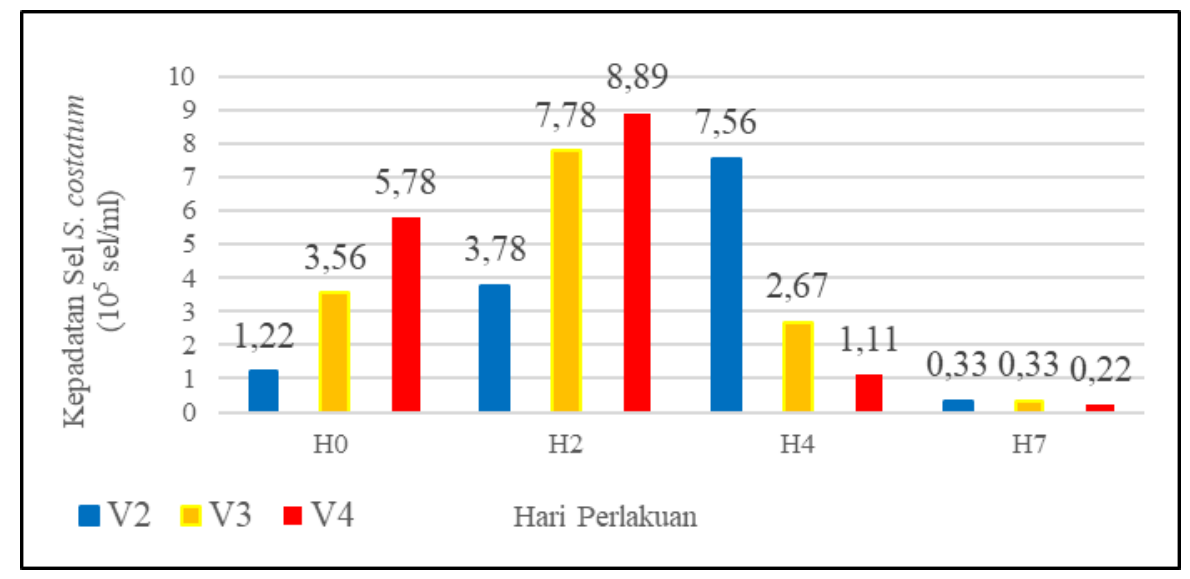

Gambar 2. Hasil Perhitungan Kepadatan Sel Skeletonema costatum pada hari ke-0, 2, 4 dan 7. Keterangan: V2= Kepadatan awal sel $S$. costatum $2 \times 10^{5} \mathrm{sel} / \mathrm{ml}$; V3= Kepadatan awal sel $S$. costatum $4 \times 10^{5} \mathrm{sel} / \mathrm{ml}$; V4= Kepadatan awalsel S. costatum $6 \times 10^{5} \mathrm{sel} / \mathrm{ml}$.

Kepadatan $S$. costatum pada perlakuan V3 dan V4 menunjukkan tren peningkatan dari $\mathrm{H}-0$ hingga $\mathrm{H}-2$, lalu terjadi penurunan dari $\mathrm{H}-$ 4 sampai $\mathrm{H}-7$. Hal ini mengindikasikan bahwa populasi mikroalga pada perlakuan V3 dan V4 memiliki fase lag yang pendek atau proses adaptasi yang lebih singkat sehingga memasuki fase log (eksponensial) lebih cepat dibandingkan perlakuan V2. Hal tersebut dapat dilihat pada Gambar 5. dengan tingkat kepadatan tertinggi pada $\mathrm{H}-2$ dengan nilai $8,89 \times 10^{5} \mathrm{sel} / \mathrm{ml}$ pada perlakuan V4 dan jumlah kepadatan $7,78 \times 10^{5} \mathrm{sel} / \mathrm{ml}$ pada perlakuan $\mathrm{V} 3$. Perlakuan V2 baru mengalami puncak pertumbuhannya pada $\mathrm{H}-4$ perlakuan dengan kepadatan sel 7,56×10 $\mathrm{sel} / \mathrm{ml}$.

Populasi S. costatum H-4 hingga H-7 pada perlakuan V3 dan V4 dan populasi $S$. costatum H-7 pada perlakuan V2 mengalami penurunan drastis kepadatan sel-nya, hal ini dapat disebabkan oleh keberadaan nutrien pada media perlakuan yang sudah berkurang (Armanda, 2013) dan disebabkan juga oleh keberadaan logam berat dalam mikroalga yang konsentrasinya tidak mampu ditoleransi lagi (Arunakumara dan Zhang, 2008). Ion logam berat, seperti $\left.\mathrm{Cd}^{2+}, \mathrm{Pb}^{2+}, \mathrm{Cu}^{2+}, \mathrm{Zn}^{2+}\right)$ memiliki kemampuan untuk berikatan dengan membran tilakoid pada kloroplas $S$. costatum yang dapat menyebabkan perubahan ultrastruktur pada organel tersebut, hal ini berakibat pada terhambatnya aktivitas fotosintesis karena diketahui pada membran tilakiod mengandung banyak kloroplas sebagai pigmen fotosintesis (Lodish et al., 2010). Fotosintesis yang terhambat dapat mengakibatkan penghambatan pertumbuhan sel mikroalga atau kematian total sel, karena melalui fotosintesis dihasilkan produk berupa karbohidrat sebagai sumber nutrisi untuk hidup mikroalga (Arunakumara dan Zhang, 2008).

Kepadatan awal $S$. costatum yang digunakan berdasarkan referensi Soedarti et al.. (2017) pada uji pendahuluan yaitu V1 $\left(5 \times 10^{3} \mathrm{sel} / \mathrm{ml}\right), \mathrm{V} 2\left(10 \times 10^{3} \mathrm{sel} / \mathrm{ml}\right)$ dan $\mathrm{V} 3$ $\left(15 \times 10^{3} \mathrm{sel} / \mathrm{ml}\right)$. Kepadatan sel awal 
ditingkatkan dari uji pendahuluan karena viabilitas sel mikroalga tidak bertahan cukup lama. Hal ini diakibatkan karena sel pada ketiga perlakuan uji pendahuluan diperkirakan inokulum yang sel-selnya tua sehingga adaptasinya lebih sulit dibandingkan pada perlakuan fikoremediasi yang sesungguhnya (V1 $\left(2 \times 10^{5} \mathrm{sel} / \mathrm{ml}\right), \mathrm{V} 2\left(4 \times 10^{5} \mathrm{sel} / \mathrm{ml}\right), \mathrm{V} 3$ $\left.\left(6 \times 10^{5} \mathrm{sel} / \mathrm{ml}\right)\right)$ yang diperkirakan memiliki sel-sel inokulum yang masih muda (sel diinokulasi pada keadaan fase eksponensial) sehingga adaptasinya lebih baik (Armanda, 2013).

\section{Kandungan Logam Berat Timbal (Pb) pada Media Perlakuan}

Hasil analisis rata-rata kandungan $\mathrm{Pb}$ pada media perlakuan dapat dilihat pada Tabel 1.

Tabel 1. Hasil Analisis Kandungan $\mathrm{Pb}$ pada Media Perlakuan

\begin{tabular}{|c|c|c|c|}
\hline Perlakuan & Kadar Awal & Kadar Akhir & Penurunan (\%) \\
\hline V1 (Kontrol negatif) & 1,122 & 1,021 & $9,03^{\mathrm{a}}$ \\
\hline $\begin{array}{l}\text { V2 (Kepadatan awal sel S. costatum } \\
\left.\qquad 2 \times 10^{5}\right)\end{array}$ & 1,122 & 0,713 & $15,83^{\mathrm{b}}$ \\
\hline $\begin{array}{l}\text { V3 (Kepadatan awal sel } S . \text { costatum } \\
\left.4 \times 10^{5}\right)\end{array}$ & 1,122 & 0,793 & $29,28^{c}$ \\
\hline $\begin{array}{l}\text { V4 (Kepadatan awal sel S. costatum } \\
\left.\qquad 6 \times 10^{5}\right)\end{array}$ & 1,122 & 0,944 & $36,45^{\mathrm{d}}$ \\
\hline
\end{tabular}

Keterangan : Angka yang diikuti dengan huruf yang sama pada baris yang sama menunjukkan tidak beda nyata, dengan tingkat kepercayaan $95 \%$.Kadar paling banyak logam $\mathrm{Pb}$ untuk kegiatan industri Batik sebesar 0,1 ppm (Peraturan Daerah Daerah Istimewa Yogyakarta No. 7, 2016).

Perlakuan V2, V3, V4 menunjukkan penurunan kadar $\mathrm{Pb}$ pada hari ke-7. Penurunan kadar $\mathrm{Pb}$ diakibatkan oleh adanya mekanisme adsorpsi, Skeletonema costatum memiliki gugus karboksil $(-\mathrm{COOH})$ yang terdapat pada asam amino penyusun protein. Gugus karboksil, gugus hidroksil, gugus karbonil pada polisakarida penyusun dinding sel mampu mengikat ion logam berat (Knauer et al., 1997; Soedarti et al., 2017). Gugus-gugus fungsi tersebut bermuatan negatif, sehingga dapat berikatan dengan ion logam seperti $\mathrm{Pb}^{2+}$ yang bermuatan positif (Sembiring et al.., 2009). S. costatum termasuk fitoplankton yang tinggi protein, kurang lebih $37 \%$ dan karbohidrat sekitar 21\% (Erlina et al., 2004), sehingga mendukung potensi mikroalga ini sebagai fikoremediator logam berat $\mathrm{Pb}$.

Mekanisme lainnya yang terjadi dalam penurunan kadar $\mathrm{Pb}$ ini adalah absorpsi, dengan dihasilkannya fitokelatin sebagai adaptasi paparan logam berat. Menurut Noctor et al. (2002), umumnya mekanisme sintesis fitokelatin akibat paparan logam berat seperti $\mathrm{Cd}, \mathrm{Pb}, \mathrm{Cu}, \mathrm{Hg}, \mathrm{Ag}, \mathrm{Cu}, \mathrm{Ni}, \mathrm{Au}$, As adalah sama. Menurut Handayanto et al. (2017) logam-logam berat yang masuk dalam sel mikroalga umumnya diikat oleh enzim $P C$ synthase atau gamma-glumamylcysteinyl dipeptidyl transpeptidase. Pengikatan ion logam berat tersebut akan mengkatalisis proses konversi glutation menjadi PC (fitokelatin).
Langkah berikutnya setelah ion logam berat diikat, diakumulasi di dalam vakuola melalui pengangkutan oleh senyawa HMT1.

Penurunan kadar $\mathrm{Pb}$ tertinggi dan dijadikan sebagai perlakuan terbaik adalah pada perlakuan V4 dengan inokulasi awal Skeletonema costatum dengan kepadatan $6 \times 10^{5}$ $\mathrm{sel} / \mathrm{ml}$ yang mampu menurunkan logam $\mathrm{Pb}$ sebesar $36,45 \%$. Perlakuan V4 paling tinggi penurunannya dan berbeda nyata dengan perlakuan V2 dan V3 menurut uji DMRT dengan signifikasi 5\%, hal ini menandakan bahwa kemampuan populasi $S$. costatum dengan inokulasi awal kepadatan $6 \times 10^{5} \mathrm{sel} / \mathrm{ml}$ paling efektif dalam menurunkan kadar logam berat timbal $(\mathrm{Pb})$ dalam limbah batik. Persentase penurunan yang diperoleh lebih rendah jika dibandingkan dengan hipotesis yang telah dibuat dan masih berada di atas Baku Mutu Air Limbah Industri Batik menurut Peraturan Daerah Istimewa Yogyakarta nomor 7 tahun 2016 (nilai baku mutu sebesar 0,1 ppm). Hal ini disebabkan karena diketahui bahwa dalam limbah yang digunakan merupakan limbah pewarna cair batik yang murni sehingga diperkirakan memiliki logam berat lainnya seperti kadmium (Cd), seng ( $\mathrm{Zn})$ dan tembaga $(\mathrm{Cu})$ (Riyawati et al., 2014; Hertiyani, 2016; Hernayati, 2004). Ion dari logam-logam tersebut $\left(\mathrm{Cd}^{2+}, \mathrm{Cu}^{2+}, \mathrm{Zn}^{2+}\right)$ mampu untuk diadsorpsi dan diabsorpsi oleh $S$. 
costatum sehingga membuat penyerapan logam $\mathrm{Pb}$ tidak efektif.

\section{Kandungan BOD pada Media Perlakuan}

Hasil analisis kadar BOD pada media perlakuan dengan penambahan alga menunjukkan penurunan. Hasil analisis ratarata kandungan $\mathrm{Pb}$ pada media perlakuan dapat dilihat pada Tabel 2 .

Tabel 2. Hasil Analisis Kandungan BOD pada Media Perlakuan

\begin{tabular}{|c|c|c|c|}
\hline Perlakuan & Kadar Awal & Kadar Akhir & Penurunan (\%) \\
\hline "V1 (Kontrol negatif) & 101,665 & 42,713 & 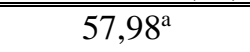 \\
\hline $\begin{array}{l}\text { V2 (Kepadatan awal sel S. costatum } \\
\left.\qquad 2 \times 10^{5}\right)\end{array}$ & 101,665 & 19,310 & $81,00^{b}$ \\
\hline $\begin{array}{c}\text { V3 (Kepadatan awal sel S. costatum } \\
\left.4 \times 10^{5}\right)\end{array}$ & 101,665 & 20,255 & $80,07^{\mathrm{c}}$ \\
\hline $\begin{array}{c}\text { V4 (Kepadatan awal sel S. costatum } \\
\left.6 \times 10^{5}\right)\end{array}$ & 101,665 & 30,913 & $69,59^{c}$ \\
\hline
\end{tabular}

Keterangan : Angka yang diikuti dengan huruf yang sama pada baris yang sama menunjukkan tidak beda nyata, dengan tingkat kepercayaan $95 \%$. Kadar paling banyakBOD untuk kegiatan industri Batik sebesar85 ppm (Peraturan Daerah Daerah Istimewa Yogyakarta No. 7, 2016).

Perlakuan kontrol, maupun V1, V2 dan V3 dari hari ke-0 hingga hari ke-7 nilai BOD mengalami penurunan nilai BOD hingga nilainya di bawah Mutu Air Limbah Industri Batik menurut Peraturan Daerah Istimewa Yogyakarta nomor 7 tahun 2016 (nilai baku mutu sebesar 85 ppm). Menurut Kasam et al.. (2009), limbah cair industri batik yang terdiri atas zat pewarna serta lilin/malam umumnya memiliki nilai $\mathrm{pH}$ yang tinggi (basa) serta memiliki kandungan zat-zat organik yang konsentrasinya tinggi. Kandungan zat-zat organik yang tinggi tersebut menyebabkan dibutuhkannya juga oksigen dalam jumlah besar untuk memecahkan materi organik tersebut, sehingga menyebabkan kandungan BOD pada limbah H-0 sangat tinggi dengan nilai 101,65 ppm (dapat dilihat pada Tabel 2). Perlakuan V2, V3 dan V4 mengalami penurunan nilai BOD, hal ini disebabkan oleh proses oksidasi bahan organik oleh organisme di dalam air media perlakuan (Pescod, 1973). Proses aerasi yang terus menerus dilakukan selama 7 hari perlakuan juga dapat meningkatkan difusi oksigen dari udara ke dalam air (Haris, 2012), dengan naiknya kadar oksigen terlarut hal ini dapat membantu bakteri aerob (bakteri indigenus dalam limbah) untuk mengurai bahan organik yang terdapat dalam limbah (Hadiyanto \& Azim, 2012).

Perlakuan V4 memiliki jumlah kepadatan sel tertinggi pada $\mathrm{H}-2$ (dapat dilihat pada Gambar 5). Hal ini berbanding lurus dengan penurunan nilai BOD-nya yang juga tertinggi (dapat dilihat pada Tabel 2) dengan persentase penurunan $81,008 \%$, namun tidak berbeda nyata dengan perlakuan V3 (inokulasi kepadatan awal $4 \times 10^{5} \mathrm{sel} / \mathrm{ml}$ ). Penurunan yang tinggi ini dapat disebabkan oleh semakin banyaknya jumlah sel $S$. costatum pada perlakuan V4 menyebabkan semakin banyak pula oksigen terlarut yang dihasilkan dari proses fotosintesis, oksigen terlarut yang tinggi tersebut dapat dimanfaatkan bakteri aerob untuk proses penguraian bahan organik (Hadiyanto dan Azim, 2012) sehingga kandungan bahan organik dalam limbah pun akan semakin banyak juga terurai.

\section{Kondisi Faktor-Faktor Lingkungan selama Fikoremediasi}

\section{Suhu}

Data selama pengamatan selama 7 hari perlakuan dapat dilihat pada Gambar 3. Hasil pengukuran suhu tiap hari selama 7 hari perlakuan bahwa nilainya konstan berada di kisaran $22-23^{\circ} \mathrm{C}$. Suhu yang konstan diakibatkan oleh pengaruh suhu ruangan laboratorium yang ditunjang oleh 2 alat Air Conditioner (AC) dengan pengaturan suhu $\pm 22^{\circ} \mathrm{C}$. Kisaran suhu ini menurut Armanda (2013) merupakan kisaran suhu optimal untuk pertumbuhan $S$. costatum sehingga diharapkan pertumbuhannya juga optimal.

\section{Salinitas}

Data perubahan salinitas yang diperoleh setiap hari pengamatan selama 7 hari perlakuan dapat dilihat pada Gambar 4 


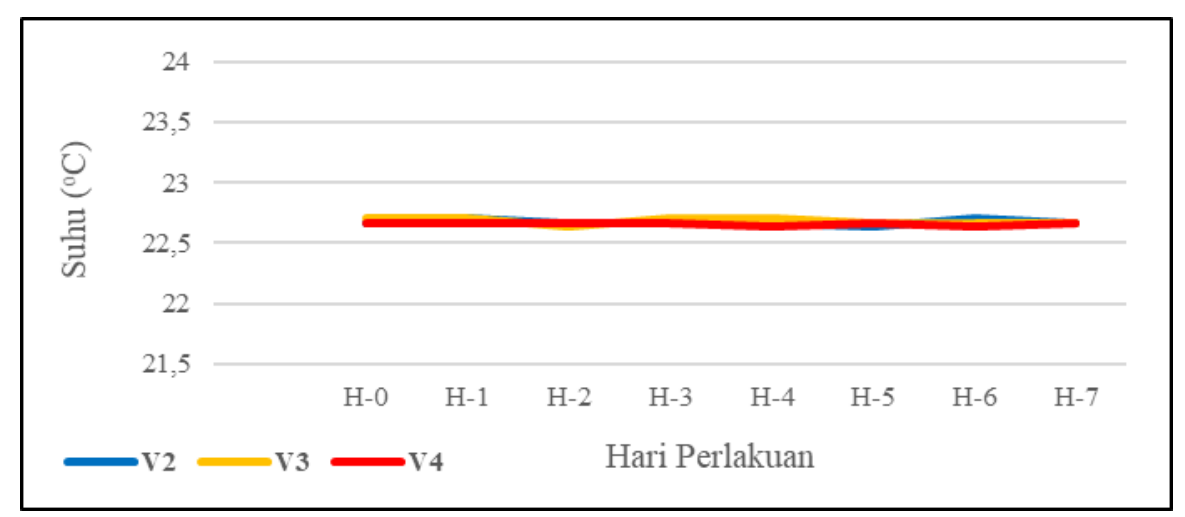

Gambar 3. Nilai Kisaran Suhu Media Perlakuan selama 7 hari

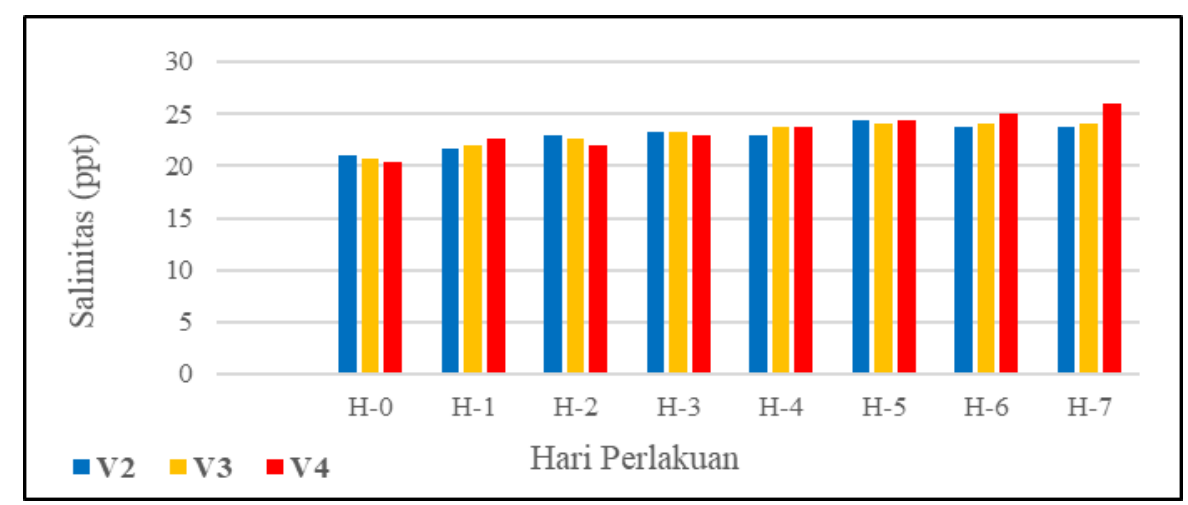

Gambar 4. Nilai Kisaran Salinitas Media Perlakuan selama 7 Hari

Hasil pengukuran salinitas menunjukkan adanya kenaikan nilai salinitas dari hari ke-0 hingga hari ke-7. Salinitas awal berada pada kisaran nilai 20 ppt lalu naik hingga mencapai nilai 25 ppt pada hari ke-7. Menurut Rudiyanti (2011), kisaran salinitas yang untuk pertumbuhan $S$. costatum adalah 20-30 ppt dan optimal pada 25-29 ppt, Wisudyawati (2014) melaporkan bahwa meskipun kisaran salinitas tersebut kurang dari salinitas optimal pertumbuhannya, $S$. costatum masih tetap dapat tumbuh.
Naiknya nilai salinitas tersebut dapat diakibatkan oleh aerasi dan pencahayaan dari lampu terus menerus, karena aerasi dan cahaya yang intens mengakibatkan adanya penguapan air laut dan meningkatkan proses transpirasi (penguapan) (Rostini, 2007).

\section{Derajat Keasaman (pH)}

Data perubahan salinitas yang diperoleh setiap hari pengamatan selama 7 hari perlakuan dapat dilihat pada Gambar 5.

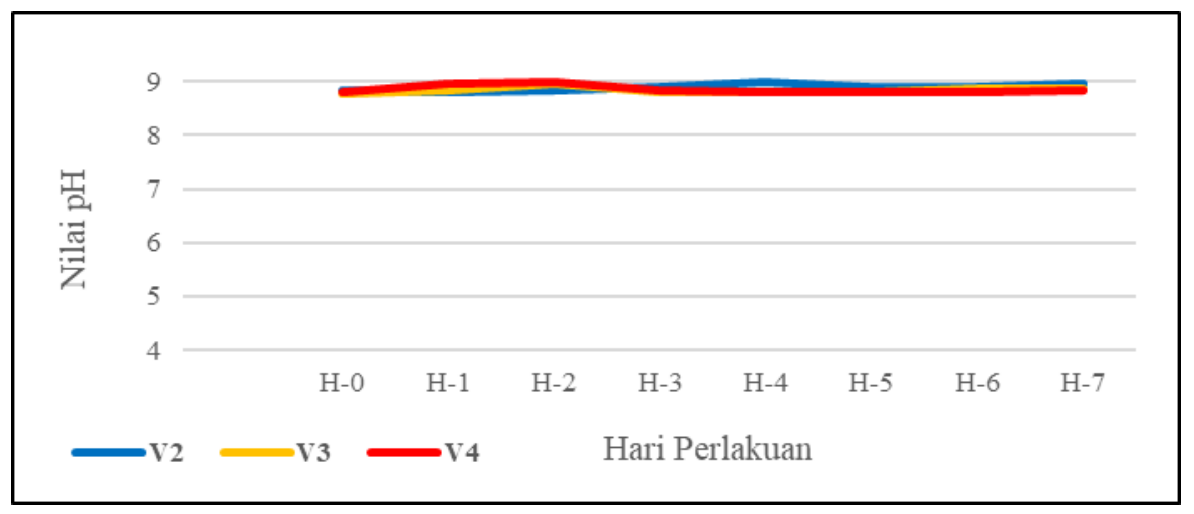

Gambar 5. Nilai Kisaran pH Media Perlakuan selama 7 Hari 
Hasil pengukuran derajat keasaman $(\mathrm{pH})$ menunjukkan peningkatan nilai $\mathrm{pH}$ dari hari ke-0 hingga hari ke-7. Hari ke-0 nilai $\mathrm{pH}$ sekitar 8,8 naik hingga 9,1 pada hari ke-7 perlakuan. Menurut Armanda (2013), kisaran pH optimal pertumbuhan $S$. costatum adalah 78, namun Wisudyawati (2014) dalam penelitiannya pada $\mathrm{pH} 8-9$, mikroalga ini dapat mentolerir perubahan $\mathrm{pH}$ tersebut dan tetap tumbuh. Perubahan $\mathrm{pH}$ tersebut tidak memengaruhi proses penyerapan logam berat $\mathrm{Pb}$ oleh $S$. costatum.

\section{Simpulan}

Perlakuan fikoremediasi dengan inokulum Skeletonema costatum $6 \times 10^{5} \mathrm{sel} / \mathrm{ml}$ (V4) paling efektif menurunkan kadar logam timbal $(\mathrm{Pb})$ dalam limbah batik dengan persentase penurunan sebesar $36,45 \%$. Penelitian lanjutan perlu dilakukan dengan meningkatkan kepadatan inokulasi awal sel mikroalga (lebih dari $6 \times 10^{5} \mathrm{sel} / \mathrm{ml}$ ) untuk mengetahui potensi maksimal fikoremediator S. costatum.

\section{Daftar Pustaka}

Armanda, D. T. 2013. Pertumbuhan kultur mikroalga diatom Skeletonema costatum (Greville) isolat Jepara pada medium $\mathrm{f} / 2$ dan medium conway. Jurnal Bioma 2(1):49-63.

Arunakumara, K. K. I. U. dan Zhang, X. 2008. Heavy metal bioaccumulation and toxicity with special reference to microalgae. Journal Ocean University Chinese 1(7):25-30.

Badan Standarisasi Nasional. 2008. Metode Pengambilan Contoh Air Permukaan Air dan Air Limbah. SNI 6989.57. 2008.

Department of Earth, Ocean and Atmospheric Science The University of British Columbia. 2012. Phyto'pediaThePhytoplankton

EncyclopaediaProject.https://www.eoas.u bc.ca/research/phytoplankton/diatoms/cent ric/skeletonema/s_costatum.html. Diakses tanggal 2 September 2018.

Erlina, A., Amini, S. dan Endrawati, H. 2004. Kajian Nutritif Phytoplankton Pakan Alami pada Sistem Kultivasi Massal.
BBPBAP Jepara. Indonesia Journal of Marine Sciences 9(4):206-210

Eskani, I. N., Carlo, I. D. dan Sulaeman. 2005. Efektivitas pengolahan air limbah batik dengan cara kimia dan biologi. Ejournal Kemenperin 22: 16-27.

Gazpers, V. 1991. Metode Perancangan Percobaan. Armica, Bandung.

Hadiyanto. dan Azim, M. 2012. Mikroalga Sumber Pangan dan Energi Masa Depan. Universitas Diponegoro, Semarang.

Handayanto, E., Nuraini, Y., Muddarisna, N., Syam, N. dan Fiqri, A. 2017. Fitoremediasi dan Phytomining Logam Berat Pencemar Tanah. Universitas Brawijaya Press: Malang.

Haris, F. 2012. Pengaruh perbedaan suhu terhadap pertumbuhan dan kadar lipid mikroalga Scenedesmus sp. yang dibudidayakan pada limbah cair tapioka. Skripsi $S$-1. Fakultas Sains dan Teknologi Universitas Islam Negeri Maulana Malik Ibrahim Malang, Malang.

Hertiyani, N. 2016. Pemanfaatan lumpur aktif untuk menurunkan seng (Zn) dalam limbah cair pewarna indigosol pada industry batik dengan penambahan bakteri indigenus. Skripsi $S$ - 1 . Fakultas Teknobiologi Universitas Atma Jaya Yogyakarta, Yogyakarta.

Kasam., Yulianto, A. dan Rahmayanti, A. E. 2009. Penurunan COD dan warna padalimbah industri batik dengan menggunakan aerobic roughing filter aliranhorizontal. Logika, 6 (1): 27-31.

Knauer, K., Behra, R. dan Sigg, L. 1997. Adsorption and uptake of copper by the green algae Scendesmus subspicatus (Chlorophyta). Journal of Phycol 33:596601.

Lodish, H., Berk, A. dan Zipursky, S. L. 2010. Photosynthetic Stages and LightAbsorbing Pigments. https://www.ncbi.nlm.nih.gov/books/NBK 21598/\# A4436. Diakses tanggal 1 April 2019.

Nassiri, Y., Mansot, J. L., Wery, J. GinsburgerVogel, T. dan Amiard, J. C. 1997. Ultraestructural and electron energy loss spectroscopy studies of sequestration mechanisms of $\mathrm{Cd}$ and $\mathrm{Cu}$ in the marine diatom Skeletonema costatum. Arch. Environ. Contam. Toxicology 33:147-155. 
Noctor, G., Gomez, L., Vanacker, H. dan Foyer, C. H. 2002. Interactions between biosynthesis, compartmentation and transport in the control of glutathione homeostasis and signalling. Journal of Experimental Botany 53(372):1283-1304.

Peraturan Daerah Istimewa Yogyakarta Nomor 7. 2016. Baku Mutu Air Limbah untuk Kegiatan Industri. https://blh.jogjaprov.go.id/pocontent/uploa ds/Perda-No-7-tahun-2016-ttg-Baku-

Mutu-Air-Limbah.pdf. Diakses tanggal 9 Oktober 2019.

Pescod, M. D. 1973. Investigation of Rational Effluen and Stream Standars for Tropical Countries. Asian Institute of Technology, Bangkok.

Riyawati, I., Hartati, I., Purwanto, H. dan Suwardiyono. 2014. Adsorpsi logam berat timbal dan kadmium pada limbah batik menggunakan biosorbent pulpa kopi terxanthasi. Dalam: Prosiding Seminat Nasional Aplikasi Sains dan Teknologi (SNAST). 15 November 2014. Yogyakarta.

Rostini, I. 2007. Kultur Fitoplankton (Chlorella sp. dan Tetraselmis sp.) pada Skala Laboratotium di Instalasi Penelitian dan Pengkajian Teknologi Pertanian Bojonegoro. Karya Ilmiah. Fakultas Perikanan dan Ilmu Kelautan Universitas Padjajaran, Bandung.

Rudiyanti, S. 2011. Pertumbuhan Skeletonema costatum pada berbagai tingkat salinitas media. Jurnal Saintek Perikanan 6(2):6976.

Selvika, Z., Kusuma, A. B. N., Herliany, E. dan Negara, B. F. S. P. 2016. Pertumbuhan Chlorella sp. pada beberapa konsentrasi limbah batubara. Depik 5(3):107-112.

Sitanggang, P. Y. 2017. Pengolahan Limbah Tekstil dan Batik di Indonesia. Departemen Teknik Kimia Institut Teknologi Bandung, Bandung. Halaman 2-3.

Soedarti, T., Maryono, L. R. dan Hariyanto, S. 2016. Bioremediation of lead ( $\mathrm{Pb}$ II) contaminated sea water by marine diatom Skeletonema costatum. Journal of Environment and Sustainability 1:124132.

Soedarti, T., Tini, S., Sucipto, H. dan Kuncoro, E. P. 2017. Bioremediation of mercury (II) contaminated seawater using the diatom Skeletonema costatum. KnE Life Sciences 2017: 62-68.
Soeprobowati, T. R. dan Hariyati, R. 2013. Potensi mikroalga sebagai agen bioremediasi dan aplikasinya dalam penurunan logam berat pada instalasi pengolahan air limbah industri. Laporan Tahunan Penelitian Fundamental. Program Studi Biologi Universitas Diponegoro, Semarang. Halaman 6-59.

Wisudyawati, D. 2014. Studi perbandingan kemampuan Skeletonema sp. Dan Chaetoceros sp. Sebagai agen bioremediasi (fito-akumulasi) terhadap logam berat timbal $(\mathrm{Pb})$. Skripsi $S-1$. Fakultas Perikanan dan Kelautan Universitas Airlangga, Surabaya. 